\title{
MITÄ AIKUISKASVATUKSESSA TUTKITAAN
}

$\mathrm{J}$ atkuva koulutus, aikuiskoulutukseen osallistuminen, ammatillisen täydennyskoulutuksen didaktiset periaatteet ja koulutuksen vaikuttavuus ovat esimerkkejä tämän hetkisistä aikuiskasvatuksen tutkijoiden suosikkiteemoista Suomessa. Tällaisen johtopäätöksen voi tehdä Jyväskylässä 12 . - 13.3.1992 järjestetyssä Aikuiskasvatuksen 2. tutkijaseminaarissa. Noin 30 tutkijaa esitteli siellä omia tutkimuksiaan.

Vaikka seminaariin eivät osallistuneetkaan läheskään kaikki aikuiskasvatuksen alueella toimivat tutkijat, voidaan tehdä joitakin johtopäätöksiä tutkimuksen suuntautumisesta ja laadusta.

Tutkimuksen kohteet ovat muuttuneet paljon viimeisten 15 vuoden aikana. Tampereen yliopisto on pitkään toiminut tiennäyttäjänä aikuiskasvatuksessa. Siellä on keskeisenä mielenkiinnon kohteena ollut vapaa sivistystyö ja esimerkiksi aikuiskoulutukseen osallistuminen. Nyt seminaarissa esiteltiin vain pari suoranaisesti kansalais- ja työväenopistojen toimintaan liittyvää tutkimusta. Vaikka esimerkiksi Turun kasvatussosiologian tutkimusyksikössä tehdään laajoja mielenkiintoisia osallistumistutkimuksia, painopiste on siirtynyt selkeästi ammatillisen täydennyskoulutuksen tutkimiseen.

$Y^{1}$ li puolet esitellyistä tutkimuksista koski ammatillista aikuiskoulutusta. Koulutustarpeen selvittäminen, julkishallinnon koulutuksen kehittäminen, erilaiset työn opinnollistamisen kokeilut ja ylipäänsä ammatillisen koulutuksen laadun parantaminen ja sen hyödyn arviointi ovat aiheita, joihin tällä hetkellä näyttää olevan mahdollista saada tutkimusrahoitusta. Rahoittajina ovat Suomen Akatemian lisäksi esimerkiksi eri ministeriöt.

Muutama esitys koski aikuiskasvatuksen tutkimusmenetelmien kehittelyä. Esimerkkeinä ovat henkilöstön kehittämisen meta-analyysi, selontekojen menetelmä, etnometodologia ja eläytymismenetelmä. Myös historiallinen lähestymistapa oli esillä: Kansalais- ja työväenopistojen hallinnon kehitys Suomessa sekä aikuiskoulutuksen laajeneminen ja tehtävien muotoutuminen Suomessa toisen maailmansodan jälkeen.

Mielestäni tutkimusaiheiden valintaa ohjaa hyvin paljon se, minkälaisiin hankkeisiin voi rahoitusta saada. Suuntaus on selkeästi se, että rahoittajat ovat kiinnostuneita aiheista, joista on saatavissa ns. välitöntä hyötyä. Ammatillisella aikuiskoulutuksella oletetaan pystyttävän vaikuttamaan yhteiskunnan ja erityisesti talouselämän kehittymiseen. Tämä lienee yksi syy siihen, että tutkimukset ovat usein välittömän hyötyyn tähtääviä ja melko pragmaattisia.

A rvioitaessa seminaarissa esitettyjen tutkimus-

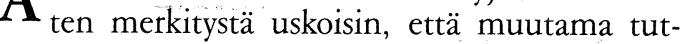
kimus voi parhaimmillaan kehittää aikuiskasvatuksen teorianmuodostusta. Muutama auttaa kehittämään entistä tehokkaampia aikuisten koulutuksen muotoja. Jotkut antavat perustietoa aikuiskasvatuksesta ilmiönä.

Monien tutkimuksien suurin hyöty näyttää olevan kuitenkin tutkijoiden oma oppiminen. Ensimmäisiä tutkimuksia tehdessään tutkija joutuu kohtaamaan niin monia vaikeasti ratkaistavia ongelmia, että varsinainen uuden tiedon luominen voi olla vaikeaa. Erityisesti silloin, kun tutkija ei lainkaan tunne kohteena olevaa ilmiötä entuudestaan, voi syntyä suoranaisia väärinkäsityksiä ja hullunkurisiakin tulosten tulkintoja. Myös tutkimusongelmien kohdentaminen olennaisiin asioihin tuottaa hankaluuksia.

Eräs tutkijoiden ongelma on aiheen vaihto niin usein, etteivät he ehdi kunnolla oppia tuntemaan kohteena olevaa ilmiötä. Kestää yleensä $5-10$ vuotta, ennenkuin tutkija on riittävän syvällä asiassa pystyäkseen luomaan jotain uutta ja merkittävää.

Tutkimusmenetelmällisesti painopiste on laadullisten menetelmien käytössä. Osallistuva observointi ja haastattelun eri muodot ovat yleisiä. 
Perinteisiä laajoihin kyselyihin perustuvia tutkimuksia esiteltiin vain muutama. Ne koskivat lähinnä osallistumista.

U seimmissa seuraamissani esityksissä käytettiin pääasiassa amerikkalaisia lähteitä. Tämä voi johtua monista syistä. Epäilemättä USA:ssa tehdään paljon hyvää tutkimusta ja tietoa osataan myydä tehokkaasti. Meidän on usein helpompi saada tietoja siellä tehdyistä julkaisuista kuin esimerkiksi pohjoismaalaisista tai jopa suomalaisista tutkimuksista. Myös nuorempien tutkijoiden kielitaidon rajoittuneisuus voi selittää melko yksipuolista kirjallisuuden seurantaa. Aikuiskasvatuksen monilta alueilta olisi saatavissa paljon virikkeitä esimerkiksi saksalaiselta tai ranskalaiselta kielialueelta.
Mielestäni Jyväskylän yliopiston Kasvatustieteiden tutkimuslaitoksen ja Aikuiskasvatuksen Tutkimusseuran järjestämä tutkijatapaaminen oli monella tavalla hyödyllinen. Tutkijoille on tärkeää saada palautetta omista töistään. Tietoa, ideoita ja uusia lähteitä välittyy tutkijoiden kesken. Vastaavan kansainvälisen foorumin tarjoaa pohjoismainen joka toinen vuosi tapahtuva tutkijaseminaari.

S eminaarin perusteella arvioituna aikuiskasvatuksen tutkimus tulee kehittymään paljon, sillä mukana oli runsaasti lahjakkaita nuoria. Olisi tärkeää myös saada mukaan useampia aikuiskasvatuksen parissa jo työskennelleitä henkilöitä, jotka tutkisivat omaa tehtäväkenttäänsä.

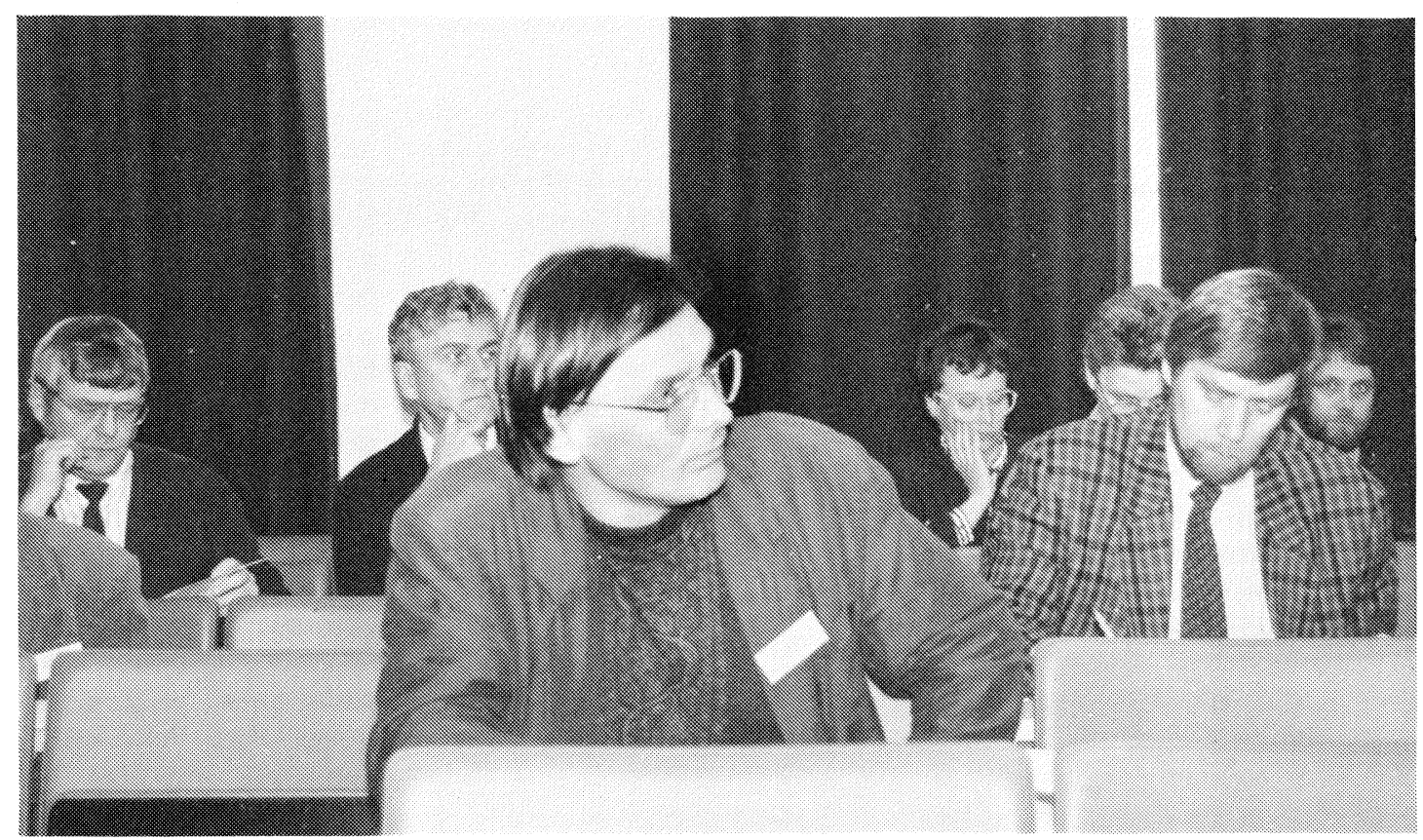

Tutkijaseminaarissa Jyväskylässä kuultiin noin 30 tutkimustyön esittely. Osallistujat jakautuivat neljään samanaikaisesti kokoontuneeseen ryhmään. 